\title{
Enkapsulasi Bakteri Asam Laktat Hasil Fermentasi Buah Salak (Salacca zalacca) Lokal Menggunakan Aginat dengan Pewarna Kembang Sepatu (Hibiscus rosa-sinensis L.)
}

\section{(Encapsulation Of Lactic Acid Bacteria From The Fermentation Of Local Zalacca Fruit (Salacca zalacca) Used Alginate with Staining of Hibiscus (Hibiscus rosa-sinensis L.))}

\author{
Christy Purukan $^{l)^{*}}$, Jainer Pasca Siampa ${ }^{l)}$, Trina Ekawati Tallei ${ }^{2)}$ \\ ${ }^{1)}$ Program Studi Farmasi, FMIPA UNSRAT Manado, 95115 \\ 2) Jurusan Biologi, FMIPA UNSRAT Manado, 95115 \\ *purukanchristy@gmail.com
}

(Article History: Received 07 Juli 2020; Revised 5 Agustus 2020; Accepted 17 Agustus 2020)

\begin{abstract}
ABSTRAK
Buah salak merupakan salah buah asli Indonesia yang dapat digunakan sebagai sumber bakteri asam laktat apabila difermentasikan. Penelitian ini bertujuan untuk melakukan enkapsulasi bakteri asam laktat hasil fermentasi buah salak menggunakan metode ekstrusi dengan pewarna kembang sepatu dan menguji viabilitas bakteri yang terenkapsulasi dengan pemaparan terhadap cairan asam lambung $\mathrm{pH} 3$. Fermentasi dilakukan selama 7 hari dan diukur kadar asam, kadar alkohol, dan enumerasi bakteri hasil fermentasi. Enkapsulasi dilakukan dengan mencampur suspensi bakteri hasil fermentasi dengan larutan alginat yang telah dicampur dengan ekstrak kembang sepatu, kemudian diteteskan menggunakan syringe volume $3 \mathrm{ml}$ dan $5 \mathrm{ml}$ dalam larutan $\mathrm{CaCl}_{2}$ sehingga membentuk beads, kemudian diuji viabilitas menggunakan cairan asam lambung $\mathrm{pH} 3$. Berdasarkan hasil penelitian didapatkan bahwa alginat dapat digunakan sebagai bahan pengkapsul bakteri hasil fermentasi buah salak dengan menggunakan ekstrak kembang sepatu sebagai pewarna alami pada kapsul. Hasil uji viabilitas menunjukkan bahwa beads yang terbentuk dari syringe volume $3 \mathrm{ml}$ lebih baik dibandingkan beads yang terbentuk dengan syringe volume $5 \mathrm{ml}$.

Kata kunci:bakteri asam laktat; enkapsulasi; fermentasi; kembang sepatu; salak.
\end{abstract}

ABSTRACT

Zalacca is a fruit native to Indonesia that can be used as a source of lactic acid bacteria (LAB) when fermented. This study aimed to encapsulate LAB obtained from the zalacca fruit fermentation using the extrusion method with hibiscus pigment as a coloring dye, and to test the viability of the encapsulated bacteria in the pH 3 of simulated gastric fluid (SGF). Fermentation was carried out for seven days and acidity and alcohol were evaluated. The number of bacteria was also enumerated. Encapsulation was carried out by mixing fermented bacterial suspension with alginate solution which had been mixed with hibiscus extract and then dripped using $3 \mathrm{ml}$ and $5 \mathrm{ml}$ volume syringes in the $\mathrm{CaCl}_{2}$ solution to form beads. The viability ov $L A B$ was tested after being exposed to SGF. Based on the result of this study it can be concluded that alginate can be used to encapsulate LAB produced from the zalacca fruit fermentation with a pigment extracted from hibiscus used as a natural dye. The viability tests indicated that the beads formed with the $3 \mathrm{ml}$ volume syringe were better than the $5 \mathrm{ml}$ volume syringe.

Keywords: lactic acid bacteria; encapsulation; fermentation; hibiscus; zalacca.

\section{PENDAHULUAN}

Proses fermentasi merupakan metode yang sudah dilakukan sejak dahulu kala untuk mempertahankan bahan pangan. Pada proses ini, bakteri-bakteri asam laktat (BAL) yang secara alamiah terdapat pada bahan pangan akan bertumbuh dengan baik, dan menguraikan senyawa-senyawa kompleks bahan pangan tersebut menjadi asam-asam organik (misalnya asam laktat) dan alkohol.

Salah satu buah asli Indonesia yang merupakan buah unggulan daerah Sulawesi Utara adalah buah salak. Menurut Utami (2018), buah salak mengandung sukrosa, fruktosa dan glukosa yang dimanfaatkan BAL selama proses fermentasi sehingga dapat dijadikan minuman probiotik. 
Usaha yang dapat dilakukan untuk mempertahankan BAL agar tetap hidup saat masuk ke lambung yang memiliki tingkat keasaman tinggi yaitu metode enkapsulasi. Enkapsulasi merupakan proses penyalutan bahan salutan berupa suatu senyawa aktif padat, cair, gas, ataupun sel dengan suatu bahan pelindung tertentu yang dapat mengurangi kerusakan senyawa aktif (Kailasapathy 2002; Krasaekoopt et al. 2003). Salah satu metode enkapsulasi yang sering digunakan yaitu metode ekstrusi karena prosesnya yang sederhana dan murah serta memberikan viabilitas probiotik yang tinggi (Solanki 2013).

Bunga kembang sepatu (BKS) merupakan salah satu bunga yang mengandung senyawa antosianin. Bunga kembang sepatu dapat digunakan sebagai bahan pewarna alami untuk makanan. Oleh sebab itu, perasan air dari BKS digunakan sebagai pewarna untuk enkapsulasi BAL hasil fermentasi buah salak. Penelitian ini bertujuan untuk melakukan enkapsulasi bakteri asam laktat hasil fermentasi buah salak menggunakan metode ekstrusi dengan pewarna kembang sepatu dan menguji viabilitas bakteri yang terenkapsulasi dengan pemaparan terhadap cairan asam lambung $\mathrm{pH} 3$.

\section{METODE}

\section{Fermentasi Buah Salak}

Sebanyak 200 gram daging buah salak Pangu yang telah dipotong kecil-kecil dan dicuci bersih dimasukkan ke dalam toples fermentasi kemudian ditambahkan air sebanyak $350 \mathrm{ml}$ dan 80 gram gula putih halus. Cairan diaduk homogen kemudian kemudian toples fermentasi ditutup. Proses fermentasi dilakukan selama 7 hari dalam keadaan anaerob. Setiap hari, kadar asam, alkohol, dan $\mathrm{pH}$ dari cairan fermentasi diukur. Bakteri asam laktat dienumerasi menggunakan MRS Agar dan Nutrient Agar dengan metode total plate count.

\section{Pengukuran pH, Kadar Asam dan Alkohol}

Nilai $\mathrm{pH}$ larutan fermentasi diukur menggunakan kertas indikator $\mathrm{pH}$. Kadar asam dan alkohol diukur menggunakan metode titrasi. Sebanyak $10 \mathrm{ml}$ larutan fermentasi ditambahkan dengan 3 tetes indikator fenolftalein kemudian dititrasi dengan $\mathrm{NaOH}$ $0,1 \mathrm{~N}$ sampai bewarna merah muda dan stabil. Titrasi kadar alkohol dilakukan hingga empat kali pengulangan. Volume hasil titrasi $\mathrm{NaOH}$ yang didapat dimasukkan ke dalam rumus perhitungan kadar asam dan alkohol.

Rumus perhitungan kadar asam menurut Jannah et al. (2014) :

Kadar Asam (\%): $\frac{V_{1} \times N \times B}{V_{2} \times 1000} \times 100 \%$

Keterangan:

$\mathrm{V}_{1}=$ Volume $\mathrm{NaOH}(\mathrm{ml})$

$\mathrm{V}_{2}=$ Volume sampel $(\mathrm{ml})$

$\mathrm{N}=$ Normalitas $\mathrm{NaOH}(0,1 \mathrm{~N})$

$\mathrm{B}=$ Berat Molekul Asam Laktat (90)

Rumus perhitungan kadar alkohol menurut Yulianti (2014) :

Kadar alkohol (\%) :

\section{$\frac{a \times M \times B E \times \text { pengenceran }}{\text { volume sampel } \times 100} \times 100 \%$}

Keterangan:

$a=$ Rata - rata $\mathrm{ml} \mathrm{NaOH} 0,1 \mathrm{~N}$

$\mathrm{M}=$ Molaritas $\mathrm{NaOH}(0,1 \mathrm{~N})$

$\mathrm{BE}=$ Berat Ekivalen Alkohol

\section{Perhitungan Pertumbuhan Bakteri}

Bakteri hasil fermentasi buah salak dihitung menggunakan total plate count dengan metode pour plate. Sebanyak $1 \mathrm{ml}$ larutan fermentasi buah salak diencerkan dengan $9 \mathrm{ml} \mathrm{NaCl} 0,9 \%$ steril untuk pengenceran $10^{-1}$. Pengenceran dilakukan sampai dengan pengenceran $10^{-5}$. Masingmasing pengenceran $10^{-1}-10^{-5}$ diambil sebanyak $50 \mu \mathrm{l}$ kemudian dituang ke dalam masing-masing cawan petri dan ditambahkan media Nutrient Agar dan MRS Agar sebanyak $15 \mathrm{ml}$ kemudian diratakan dengan cara memutar cawan petri dengan perlahan dan didiamkan hingga media memadat.

Masing-masing cawan petri dibungkus dengan plastic wrap dan aluminium foil lalu diinkubasi selama 48 jam pada suhu $37^{\circ} \mathrm{C}$. Setelah 48 jam diinkubasi, koloni yang tumbuh dihitung menggunakan colony counter kemudian jumlah koloni yang terhitung dimasukkan dalam rumus perhitungan total plate count. Menurut Pradikaningrum (2015), rumus perhitungan total plate count untuk mendapatkan jumlah sel (CFU) yaitu: 


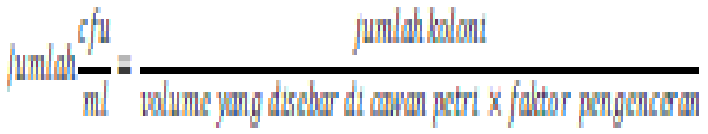

\section{Ekstraksi Bunga Kembang Sepatu}

Sebanyak 50 gram kelopak bunga kembang sepatu yang masih segar dicuci dengan air bersih kemudian di blender dengan air sebanyak $50 \mathrm{ml}$. Kelopak bunga kembang sepatu yang telah di blender kemudian diperas menggunakan kain bersih. Hasil perasaan ekstrak bunga kembang sepatu digunakan sebagai pewarna dalam pembuatan larutan natrium alginat.

\section{Enkapsulasi Bakteri Hasil Fermentasi}

Larutan natrium alginat sebagai bahan penyalut dibuat dengan melarutkan 1 gram natrium alginat dalam $50 \mathrm{ml}$ ekstrak bunga kembang sepatu kemudian disterilkan dengan cara dipanaskan dengan suhu tidak lebih dari $50^{\circ} \mathrm{C}$. Larutan $\mathrm{CaCl}_{2}$ sebagai bahan pengeras dibuat dengan melarutkan 1,47 gram $\mathrm{CaCl}_{2}$ dalam $100 \mathrm{ml}$ akuades kemudian diaduk hingga homogen dan disterilkan dengan autoklaf pada suhu $121^{\circ} \mathrm{C}$ selama 15 menit.

Suspensi bakteri untuk enkapsulasi diperoleh dengan menginokulasi $1 \mathrm{ml}$ cairan fermentasi pada hari ke-4 ke dalam $50 \mathrm{ml}$ media MRS Broth kemudian diinkubasi selama 24 jam pada suhu $37^{\circ} \mathrm{C}$. Setelah diinkubasi, suspensi bakteri dicampurkan dengan larutan natrium alginat. Proses enkapsulasi dengan metode ekstrusi dilakukan dengan cara meneteskan campuran suspensi bakteri dan larutan natrium alginat ke dalam larutan pengeras
$\left(\mathrm{CaCl}_{2}\right)$ menggunakan syringe volume $3 \mathrm{ml}$ dan $5 \mathrm{ml}$ hingga terbentuk beads.

\section{Uji Viabilitas pada Cairan Asam Lambung}

Sebanyak 1 gram bakteri hasil fermentasi yang terenkapsulasi dimasukkan ke dalam tabung reaksi yang berisi $10 \mathrm{ml}$ cairan simulasi asam lambung dengan $\mathrm{pH} 3$ dan diinkubasi pada suhu $37^{\circ} \mathrm{C}$ selama 120 menit. Setelah diinkubasi, bakteri terenkapsulasi dicuci dengan larutan $\mathrm{NaCl}$ $0,9 \%$ steril kemudian ditimbang lagi berat beads yang tersisa. Beads yang tersisa dilarutkan dalam $\mathrm{NaCl}$ 0,9\% steril kemudian diencerkan hingga pengenceran $10^{-5}$. Bakteri yang diencerkan dienumerasi menggunakan media Nutrient Agar dan MRS Agar dengan metode total plate count.

\section{HASIL DAN PEMBAHASAN \\ Fermentasi Buah Salak}

Proses fermentasi selama 7 hari menghasilkan kadar asam dan kadar alkohol (Tabel 1). Peningkatan kadar asam dan alkohol setiap hari disebabkan oleh adanya penguraian substrat yang ada pada daging buah salak sehingga menghasilkan air, oksigen, energi dan sejumlah asam organik lainnya seperti asam laktat, asam asetat, etanol serta bahan-bahan organik yang mudah menguap (Muchtadi dan Ayustaningwarno 2010). Bakteri asam laktat yang dihasilkan pada proses fermentasi memiliki peranan dalam memproduksi senyawa-senyawa berupa asam organik dan etanol sehingga terjadi peningkatan kadar asam dan kadar alkohol setiap hari saat dilakukan fermentasi.

Tabel 1. Kadar asam dan kadar alkohol pada larutan fermentasi buah salak

\begin{tabular}{crrrr}
\hline Hari Ke- & \multicolumn{2}{c}{ Kadar Asam (\%) } & \multicolumn{2}{c}{ Kadar Alkohol (\%) } \\
\cline { 2 - 5 } & $\begin{array}{c}\text { Fermentasi Buah } \\
\text { Salak }\end{array}$ & Blanko & \multicolumn{1}{c}{$\begin{array}{c}\text { Fermentasi Buah } \\
\text { Salak }\end{array}$} & \multicolumn{1}{c}{ Blanko } \\
\hline 1 & 0,0585 & 0,018 & 0,2806 & 0,092 \\
2 & 0,1305 & 0,018 & 0,7268 & 0,1012 \\
3 & 0,297 & 0,054 & 1,5318 & 0,2576 \\
4 & 0,603 & 0,108 & 2,8336 & 0,483 \\
5 & 0,675 & 0,1215 & 3,5098 & 0,5566 \\
6 & 0,765 & 0,162 & 3,703 & 0,805 \\
7 & 1,089 & 0,3105 & 4,8852 & 1,2282 \\
\hline
\end{tabular}


Peningkatan kadar asam dalam larutan fermentasi menyebabkan terjadi penurunan nilai $\mathrm{pH}$ pada larutan fermentasi (Tabel 2). Penurunan nilai $\mathrm{pH}$ pada larutan terjadi karena senyawa-senyawa asam organik yang dihasilkan bakteri asam laktat (Reis et al. 2012).

$\begin{array}{lll}\text { Tabel 2. Pengukuran } & \mathrm{pH} & \text { hasil } \\ \text { fermentasi buah salak }\end{array}$

\begin{tabular}{ccc}
\hline Hari ke- & $\begin{array}{c}\text { Fermentasi } \\
\text { Buah Salak }\end{array}$ & Blanko \\
\hline 1 & 4 & 7 \\
2 & 4 & 5 \\
3 & 4 & 5 \\
4 & 4 & 5 \\
5 & 3 & 4 \\
6 & 3 & 4 \\
7 & 3 & 3 \\
\hline
\end{tabular}

Pertumbuhan koloni bakteri pada media NA dan MRSA sudah sesuai dengan prinsip faktor pengenceran. Tidak semua data jumlah koloni pada setiap pengenceran dapat dihitung karena jumlah koloninya kurang dari batas minimum atau lebih dari batas maksimum dalam standar perhitungan total plate count. Menurut Fardiaz (2004) standar minimum untuk perhitungan total plate count ialah 30 koloni, sedangkan untuk batas maksimumnya sebanyak 300 koloni.

Pertumbuhan bakteri pada media MRSA yang merupakan media selektif untuk pertumbuhan bakteri asam laktat menunjukkan adanya peningkatan dari hari pertama sampai hari ke 6 dan terjadi penurunan pada hari ke 7 (Gambar 1). Penurunan jumlah bakteri dapat disebabkan oleh substrat dalam larutan fermentasi yang menjadi sumber utama perkembangbiakan bakteri asam laktat sudah hampir habis (Kiani et al. 2008). Bakteri asam laktat memiliki sifat bakteriosin sehingga walaupun terjadi peningkatan pertumbuhan jumlah bakteri pada media NA, jumlah bakteri yang tumbuh tidak melebihi jumlah bakteri asam laktat yang tumbuh pada media MRSA (Perez et al. 2014).

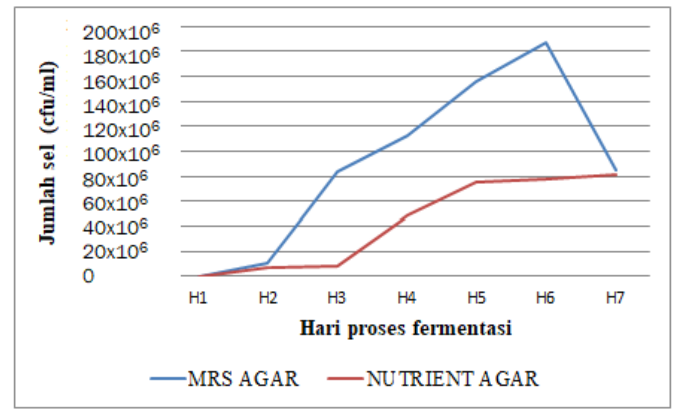

Gambar 1. Grafik pertumbuhan bakteri

\section{Ekstraksi Kembang Sepatu}

Warna merah diambil sebagai pewarna untuk enkapsulasi. Warna merah pada bunga kembang sepatu dihasilkan dari senyawa antosianin sebagai pigmen dari bunga kembang sepatu. Ektraksi bunga kembang sepatu untuk menghasilkan warna merah dilakukan dengan metode ektraksi segar (Oktiarni et al. 2013).

\section{Enkapsulasi Bakteri Hasil Fermentasi dengan Pewarna Kembang Sepatu}

Beads yang terbentuk pada proses enkapsulasi menunjukkan adanya perbedaan bentuk dan ukuran karena penggunaan syringe dengan 2 volume yang berbeda. Syringe dengan volume $3 \mathrm{ml}$ menghasilkan bentuk beads yang lebih padat dan lebih mudah terbentuk dibandingkan dengan beads yang terbentuk menggunakan syringe volume $5 \mathrm{ml}$. Pencampuran ekstrak bunga kembang sepatu dengan alginat menghasilkan warna merah pada beads (Gambar 2).

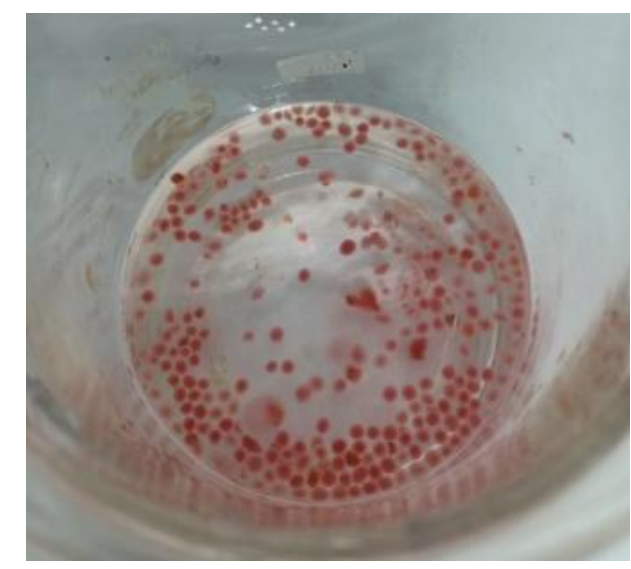

Gambar 2. Enkapsulasi dengan pewarna ekstrak kelopak bunga kembang sepatu 
Pada proses enkapsulasi menggunakan metode ekstrusi, alginat dan $\mathrm{CaCl}_{2}$ yang digunakan sebagai bahan pengkapsulan dan bahan pengeras dapat meningkatkan kekuatan beads (Chandramouli et al. 2004). Menurut Krasaekoopt et al. (2003) bawa jarak antara syringe dengan larutan $\mathrm{CaCl}_{2}$ dapat mempengaruhi bentuk dan ukuran beads.

\section{Uji Viabilitas}

Pengujian dalam simulasi cairan lambung dengan $\mathrm{pH} 3$ di dilakukan terhadap beads hasil enkapsulasi. Hal ini dilakukan untuk melihat ketahanan enkapsulasi dalam melindungi bakteri saat melewati $\mathrm{pH}$ dengan keasaman yang ekstrim. Hasil ketahanan beads yang terbentuk dari kedua volume syringe yang berbeda dilihat dari berat dan jumlah bakteri yang tumbuh setelah dilakukan pengujian.

Berdasarkan berat dari beads setelah dilakukan pengujian menunjukkan bahwa beads yang terbentuk dengan syringe volume $3 \mathrm{ml}$ lebih baik karena bobot beads yang berkurang yaitu 0,2 gram dari 1 gram. Sedangkan beads yang terbentuk dengan syringe volume $5 \mathrm{ml}$ terjadi pengurangan bobot sebanyak 0,3 gram dari 1 gram. Hal tersebut merupakan kelebihan dari bentuk enkapsulasi dengan ukuran kecil sehingga dapat melindungi suatu senyawa dari penguraian (Babstov 2002).

Hasil perhitungan bakteri yang telah dienkapsulasi yang tumbuh pada media
MRSA dan NA dibandingkan dengan pertumbuhan bakteri yang tumbuh pada larutan fermentasi hari ke 4. Beads yang terbentuk dari 2 volume syringe yang berbeda menunjukkan hasil pertumbuhan bakteri yang berbeda. Hasil pertumbuhan bakteri yang telah dienkapsulasi pada kedua media agar saat dibandingkan dengan bakteri yang tidak dienkapsulasi dari larutan fermentasi hari ke4 menunjukkan adanya penurunan jumlah bakteri yang disebabkan karena pengurangan jumlah bobot pada pengujian viabilitas enkapsulasi (Tabel 3).

Hasil perhitungan total plate count pada media MRSA dan NA menunjukkan jumlah bakteri yang tumbuh dari beads dengan volume syringe $3 \mathrm{ml}$ lebih banyak dibandingkan dengan jumlah bakteri yang tumbuh dari beads dengan volume syringe 5 ml (Tabel 3).

Pengurangan bobot pada beads dari kedua volume syringe yang berbeda satu sama sama lain sesuai dengan perbedaan jumlah bakteri yang tumbuh dari kedua jenis beads setelah diuji. Hasil pengukuran berat beads dan jumlah bakteri yang tumbuh pada media MRSA dan NA menunjukkan bahwa beads yang terbentuk dari syringe dengan volume $3 \mathrm{ml}$ memiliki viabilitas yang lebih baik dibandingkan dengan beads yang terbentuk dari syringe dengan volume $5 \mathrm{ml}$ karena menurut Babstov (2002), enkapsulasi dalam ukuran kecil memiliki kelebihan untuk melindungi suatu senyawa.

Tabel 3. Total plate count bakteri terenkapsulasi setelah diinkubasi dengan simulasi cairan asam lambung pada media MRSA dan NA

\begin{tabular}{|c|c|c|c|c|c|c|c|c|c|c|c|c|}
\hline \multirow{3}{*}{$\begin{array}{l}\text { Volume } \\
\text { Syringe }\end{array}$} & \multicolumn{10}{|c|}{ Jumlah Koloni/Media } & \multicolumn{2}{|c|}{ Total $(\mathrm{cfu} / \mathrm{ml})$} \\
\hline & \multicolumn{2}{|c|}{$10^{-1}$} & \multicolumn{2}{|c|}{$10^{-2}$} & \multicolumn{2}{|c|}{$10^{-3}$} & \multicolumn{2}{|c|}{$10^{-4}$} & \multicolumn{2}{|c|}{$10^{-5}$} & \multirow[b]{2}{*}{ MRS } & \multirow[b]{2}{*}{ NA } \\
\hline & MRS & NA & MRS & NA & MRS & NA & MRS & NA & MRS & NA & & \\
\hline $3 \mathrm{ml}$ & - & - & - & 245 & 37 & 228 & - & 136 & - & - & $0,74 \times 10^{6}$ & $10,75 \times 10^{6}$ \\
\hline $5 \mathrm{ml}$ & - & - & 116 & 134 & 45 & 100 & - & 35 & - & - & $0,566 \times 10^{6}$ & $9,268 \times 10^{6}$ \\
\hline
\end{tabular}

Ket :

$10^{-1}$ : Jumlah koloni pada pengenceran $10^{-1} ; \quad 10^{-2}$ : Jumlah koloni pada pengenceran $10^{-2}$

$10^{-3}$ : Jumlah koloni pada pengenceran $10^{-3} ; \quad 10^{-4}$ : Jumlah koloni pada pengenceran $10^{-4}$

$10^{-5}$ : Jumlah koloni pada pengenceran $10^{-5}$ 


\section{KESIMPULAN}

Enkapsulasi bakteri hasil fermentasi buah salak dapat dilakukan menggunakan polimer alginat dengan pewarna ekstrak bunga kembang sepatu dalam metode ekstrusi. Penggunaan alginat sebagai enkapsulan dan $\mathrm{CaCl}_{2}$ sebagai bahan penyalut dapat meningkatkan kekuatan beads. Pada pengujian viabilitas menunjukkan bahwa syringe membentuk beads mempengaruhi viabilitas dari bakteri-bakteri yang telah terenkapsulasi.

\section{DAFTAR PUSTAKA}

Babtsov (2002) Method of mircroencapsulation. US Patent, US.

Chandramouli V K, Kalasapathy P, Peiris, Jones M (2004) An Improved method of microencapsulation and its evaluation to protect Lactobacillus spp. In Simulated Gastric Conditions. J Microbiol Meth 56: 27-35.

Fardiaz (2004) Analisa mikrobiologi pangan. Raja Grafindo Persada, Jakarta.

Jannah AM, Legowo YB, Pramono AN, Al-Baarri, Abduh SBM (2014) Total bakteri asam laktat, $\mathrm{pH}$, keasaman, citarasa dan kesukaan Yogurt Drink dengan penambahan ekstrak buah belimbing. Jurnal Aplikasi Teknologi Pangan 3(2): 7-11.

Kailasapathy K.

Microencapsulation of probiotic bacteria: technology and potential applications. Curr. Issues Intest. Microbiol 3: 39-48.

Kiani H, Mousavi SMA, Zahra ED (2008). Rheological properties of
Iranian Yoghurt Drink, Doogh. International Journal of Dairy Science 3(2): 71-78.

Krasaekoopt W, Bhandari B, Deeth H (2003). Evaluation of encapsulation techniques of Probiotics for Yoghurt. Int Dairy Journal 13: 3-13.

Muchtadi, T., dan F. Ayustaningwarno. 2010. Teknologi Proses Pengolahan Pangan. Institut Pertanian Bogor Press, Bogor.

Oktiarni D. Devi R, Bomilia S (2013) Pemanfaatan ekstrak bunga kembang sepatu (Hibiscus rosa sinensis Linn.) sebagai Pewarna alami dan pengawet alami pada mie basah. Prosiding Semirata FMIPA Universitas Lampung, Lampung.

Pradikaningrum H (2015) Uji viabilitas mikroenkapsulasi Lactobacillus casei menggunakan matrik kitosan. Skripsi. Program Studi Farmasi Fakultas Kedokteran dan Ilmu Kesehatan UIN Syarif Hidayatullah. Jakarta.

Reis JA, Paula AT, Casarotti SN, Penna ALB (2012) Lactic Acid antimicrobial compounds: characteristics and applications. Food Engineering and Technology 4: 124-140.

Solanki HK, Pawar DD, Dushyant AS, Prajapati VD, Jani GK, Mulla AM, Thakar PM (2013) Development of microencapsulation delivery system for long-term preservation of probiotis as biotherapeutics agent. BioMed Research International: 1-21.

Yulianti CH (2014) Uji beda kadar pada tape beras, ketan hitam dam singkong. Jurnal Teknika 1(6): 531-536. 